INDEPENDENT JOURNAL OF MANAGEMENT \& PRODUCTION (IJM\&P)

http://www.ijmp.jor.br

v. 11, n. 7, November - December 2020

ISSN: 2236-269X

DOI: 10.14807/ijmp.v11i7.1201

\title{
RELATIONSHIP BETWEEN FOOD INDUSTRIES MATURITY AND QUALITY CERTIFICATION
}

\author{
Carla C. A. Estorilio \\ Universidade Tecnológica Federal do Paraná (UTFPR), Brazil \\ E-mail: carlaegc@hotmail.com
}

Lígia de Oliveira Franzosi Bessa Federal University of Paraíba (UFPB), Brazil

E-mail: ligiafranzosi@hotmail.com

Submission: 12/12/2019

Revision: $1 / 7 / 2020$

Accept: 2/19/2020

\section{ABSTRACT}

Purpose: The purpose of this paper is to analyze the PDP (Product Development Process) maturity level in the food industry to identify the compatibility status of their quality certification and their maturity level.

Design/methodology/approach: A bibliographical review was conducted about product development, maturity process, and Capability Maturity Model Integration (CMMI). An adapted method from CMMI was used, which allows evaluating the level of maturity, through a semi-structured questionnaire. The questionnaires were applied in five companies of this industry and then, an analysis of the information obtained in each company was carried out and compared, aiming to understand the sector maturity.

Findings: After conducting the interviews in each company, the median of each group of questions was calculated, according to the methodology described. Data collected from this sector show consistency between certification time and maturity level.

Research limitations/implications: Due to the low number of respondents, this data cannot be generalized to this sector, being considered only an indication of the situation of the food industry located in Curitiba region.

Practical implications: This study shows the relationship between the maturity level of food industry and ISO 9001 quality certification. The study shows that for the company to obtain an ISO certification, it must have been at least maturity level 2, highlighting, as well, the main deficiencies of this sector. 
DOI: 10.14807/ijmp.v11i7.1201

Originality/value: The original value is to show the relationship between the maturity level of food industry and ISO 9001 quality certification.

Keywords: quality certification; food industry; maturity level

\section{INTRODUCTION}

Aiming to achieve or maintain the competitive level demanded by the global market, the food industries are searching for implement control programs in their quality management processes (MELLO, 2002).

In the pursuit of quality evidence for the consumer market, companies seek quality certifications, such as the Brazilian Standard (NBR) ISO 9001. However, companies fail to meet the minimum requirements to obtain this certification, or when they get it, they lose it in a short time.

Several initiatives have emerged related to this subject: Jochem et al. (2011) present a maturity model to measure and evaluate the process quality. This model allowed companies to determine their status and take the necessary actions to contribute to the process improvement. Garzaz et al. (2013) present the ISO adaptation in the creation of an organizational maturity model that allows the certification of organizational maturity and assists in quality improvement. Thelen (1997) focuses on how to integrate ISO 9000, BPI (Business Process Improvement) and TQM (Total Quality Management). Păunescu and Acatrinei (2012) evaluate several models and suggest a model to help organizations to achieve sustainability, and monitor and evaluate their processes performance.

In short, there are many initiatives to help a company to improve their maturity level and, consequently, their process quality. However, one of the robust methods used is the CMMI (Capability Maturity Model Integration), created by Software Engineering Institute (SEI), which serves as an improvement guide (OLIVEIRA; FLORIAN, 2013).

Several authors mention that there is a certain relationship between maturity and quality of industrial processes, which tends to reflect on the product resulting from this process. Among these studies, Vaz (2010) and Lisboa (2010) conducted some surveys in two industrial sectors (electro-electronics and motorcycle) and identified a strong relationship between the companies' maturity level and their certification status. They concluded that companies with low maturity level usually do not have ISO Certification and companies with high maturity level obtain ISO Certification and maintain it for a long term. 
DOI: 10.14807/ijmp.v11i7.1201

Eriksson et al. (2016) identified and explored the challenges that organizations face in relation to quality and investigated how maturity models incorporate this challenge. Dellana and F. Kros (2014) examined the maturity of quality management in industries and supply chains. Power (2014) compared high-tech Chinese companies with other international companies in terms of competence, capacity and quality maturity. Other studies dealt with the difficulties that small and medium-sized enterprises (SMEs) face in order to increase the maturity processes with the implementation of management models (GHOBADIAN; GALLEAR, 1997; ESCRIG; MENEZES, 2016).

Tonini et al. (2008) established that quality and maturity models could help each other in a work of process improvement, but they did not show how to achieve it. Bamford and Deibler (1993) compared IS0 9001 with CMM (Capability Maturity Model), showing that the two models should be employed together. However, the authors do not explain or detail this proposition. David et al. (2005) used CMM as a method to support process improvement, using it as a guideline to define an approach for management and control of a set of concurrent development activities.

However, this study did not identify any research specifically aimed at understanding the impact of quality certification on the company's maturity and vice versa, and few focus on manufacture industry - in particular, in the food industry. Quintella and Rocha (2007) used a simplified version of CMMI in automotive companies, all of them with quality certifications, aiming to identify their maturity levels. Among the results, the authors highlight this relation, showing that the sectors with a minimum maturity level of 2 had quality certification; however, the study's main focus did not address this type of discussion - maturity level and quality certification.

Considering the research opportunity, this paper seeks to understand the impact of quality certification on the company's maturity and vice versa, focusing on food industry. Thus, this work applies the method proposed by Quintella and Rocha (2207) in a study of multiple cases, in order to understand this correlation in food industry. The case study was conducted according to the guidelines proposed by Yin (2011), performed in five companies of the food industry.

\section{PDP, MATURITY PROCESS AND CERTIFICATION}

The Product Development Process (PDP) consists of a set of activities that try to obtain the specifications of a product and its design, aiming to manufacture it (ROZENFELD et al., 
DOI: 10.14807/ijmp.v11i7.1201

2006). The main phases are predevelopment, development, and post-development. The "development" phase consists of the stages of design, manufacturing planning and manufacture of an industrial product, which is the focus of this research.

In this stage, the design phase is the most critical because it involves a series of uncertainties typical of the initial phase of the process. Pahl and Beitz (2013), Back et al. (2008) and Rozenfeld et al., 2006 suggest that the development takes place in four phases: task definition, conceptual design, preliminary design and detailed design. In the preliminary design, various methods can be used, aiming to support these definitions (ESTORILIO; POSSO, 2010; ESTORILIO et al., 2008).

According to Fuller (2016), the PDP stages in food industry do not show these phases and sometimes they occur simultaneously. Considering the "development" stage, the author suggests the following phases for the food industry:

a) Buyers' Market: identifying consumer's needs;

b) Ideas: creating ideas from diverse sources (people in the company, sales points);

c) Identified ideas: the raised ideas are conceptualized by analyzing their viability;

d) Development: creation of the product specifications, and analysis of the cost of materials information, ingredients, packaging and equipment;

e) Pilot Test: development of a prototype product similar to the real one;

f) Production: the product is effectively produced; however, it can be altered due to the appearance of new decision variables and, in this case, its viability is evaluated again;

g) Consumer/Market Test: in this stage, the company defines the place where the market test will be performed according to the product specifications. The product is analyzed by the consumer market of the place chosen in order to predict its acceptability. Based on this, the company makes the necessary changes in the product or remove it from the market, if the expected return does not occur.

The PDP needs an efficient management (LOURENZANI et al., 2002); after all, the PDP performance is directly related to its maturity level.

\subsection{Maturity Process}

Helgesson et al. (2012) state that a mature process is defined, managed, measured, controlled and effective, whose organizations achieve quality objectives, deadlines and costs 
DOI: 10.14807/ijmp.v11i7.1201

in a consistent and effective way. Immature organizations create goals, but often their quality is not the desired ones and the time and cost may be higher than planned.

One of the earliest models of maturity levels emerged in the 1970s, called "Quality Management Maturity Enhancement," which measured five evolutionary stages of a company: Uncertainty, Awakening, Clarification, Wisdom, and Certainty. These principles were adapted in 1986, in the Software Engineering Institute (SEI), in Carnegie Mellon University, resulting in several methods evolutions, until reaching CMMI-DEV 1.3 version (QUINTELLA; ROCHA, 2007; SEI, 2010; TEAM, 2011).

\subsection{CMMI Fundamentals}

CMMI evaluates a company providing a diagnosis ranging from level 2 to 5 , or considering part of its process, scoring it from 1 to 5 . In both cases, the maturity level increases with the number given: (1) defined, (2) managed, (3) measured, (4) controlled and (5) effective (LOCKAMY; MCCORMACK, 2004). The five levels are defined as follows:

a) Level 1 - Initial - Corrective activities: it has inefficient planning and compromises are always reactive;

b) Level 2 - Managed: the projects have the requirements, products and services managed, and the processes are planned, performed, measured and controlled. The commitments are made as required and the products are reviewed in order to verify if those requirements are being met;

c) Level 3 - Defined: the processes are well characterized and understood, and described according to the standards and procedures. The processes are established, documented, integrated and improved over time. The management establishes objectives based on standard processes and ensures that these are followed and that the training is provided as required;

d) Level 4 - Quantitatively managed: the organization sets the quantitative product quality targets and the process performance targets. The projects include statistical control of products and processes and are managed throughout the life of a process. The risks associated with the application in a new domain are known and understood;

e) Level 5 - Optimization: Focus on continuous improvement of process performance, measuring objectives established and revising them to reflect the business changes, being used as a criterion for management improvement. The learned lessons are disseminated to 
DOI: 10.14807/ijmp.v11i7.1201

other projects and the process improvement becomes part of everyone's activity, leading to a cycle of continuous improvement.

To check the overall the company's maturity level, CMMI uses the "staged representation". However, when the intention is to assess the maturity of a specific area, it uses the "continuous representation". Considering that the focus of this work is to approach the overall maturity of the process, only the "staged representation" will be addressed in this review.

The staged representation presents the five levels of maturity previously described. For the company to reach a certain level, it is necessary to check if the company is servicing a set of Process Areas (PAs) belonging to a certain level review, including its goals and practices that, when executed, satisfy a set of goals. Table 1 shows what combination of goals and practices is necessary to be accomplished to obtain the evolution from the level 2, to 3, 4, or 5 . In total, the CMMI considers 22 PAs.

Table 1: Process area involved to reach a certain maturity level

\begin{tabular}{|c|c|}
\hline Maturity Level & Process area (PAs) \\
\hline \multirow{7}{*}{2} & Project Planning \\
\hline & Project Control and Monitoring \\
\hline & Suppliers Contract Management \\
\hline & Requirements Management \\
\hline & Configuration Management \\
\hline & Quality Assurance of Product and Process \\
\hline & Measurement and Analysis \\
\hline \multirow{11}{*}{3} & Focus on Organizational Process \\
\hline & Definition of Organizational Process \\
\hline & Organizational Training \\
\hline & Integrated Project Management \\
\hline & Risks Management \\
\hline & Development of Requirements \\
\hline & Technical solution \\
\hline & Integration of Product \\
\hline & Verification \\
\hline & Validation \\
\hline & Resolution and Analysis of Decision \\
\hline \multirow{2}{*}{4} & Performance of Organizational Process \\
\hline & Quantitative Management of Project \\
\hline \multirow{2}{*}{5} & Organizational Development and Innovation \\
\hline & Resolution and Analysis of the Causes \\
\hline
\end{tabular}

Source: Adapted of SEI (2010).

Each PA has several Specific Goals (ME), which refer to the execution of several Specific Practices (PE). In the process, they are also considered as Generic Goals (MG) and Generic Practices (PG). A PA is evaluated as "satisfied” only if all "crossings" between each 
DOI: 10.14807/ijmp.v11i7.1201

PE and PG are "satisfied”. If one crossing is evaluated as “unsatisfied”, the respective PA will be considered “unsatisfied” (SEI, 2010).

The company needs to reach all PAs from determined level to accomplish this specific level and all levels precedents need to be accomplished as well. Figure 1 shows a structure linked to the PAs belonging to evaluation 2, considering how these crossings are formed to promote the evaluation.

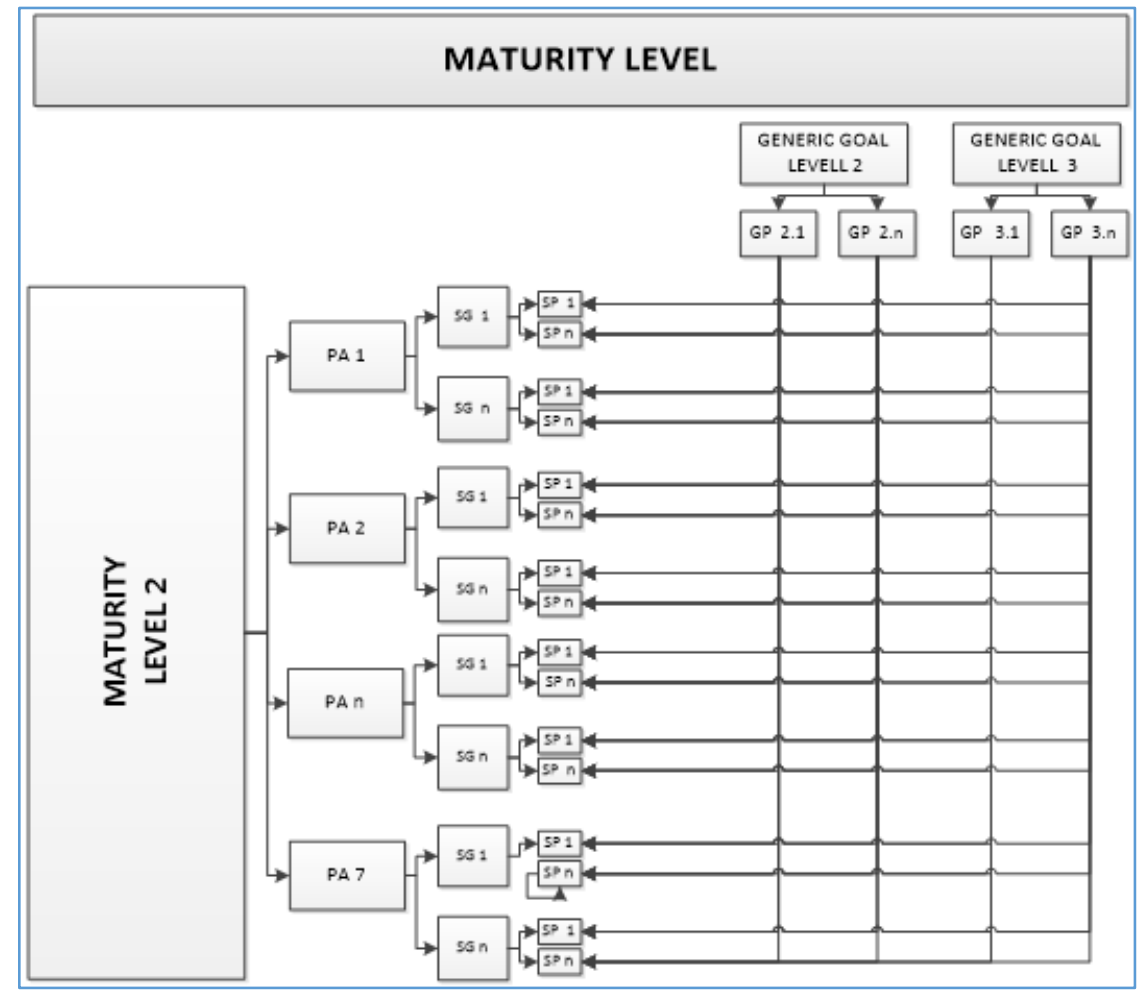

Figure 1: Variables evaluated to satisfy the maturity levels Source: authors (Estorilio et al., 2015).

The difficulty found for a full staged evaluation with CMMI is the number of variables involved in the analysis, since the number of crossings between PE and PG necessary to evaluate all maturity levels is 2665. Considering only the evaluation level 2, where most organizations are — including those certified by ISO — it means that there are 570 variables to be verified. Therefore, the authors chose to use the CMMI adapted by Quintela and Rocha (2007) in this work, which includes fewer questions to be verified in the company.

\subsection{Method Adapted From CMMI}

Quintela and Rocha (2007) propose a method based on CMMI concepts. This method is composed of 27 questions, divided into four groups, identified as key issues. Each group of questions represents the goals that the company must meet to be at a certain maturity level, as shown in Table 2. The maturity levels are as follows: 1-Few controls and unpredictable; 
DOI: 10.14807/ijmp.v11i7.1201

2 - Some tasks are repeatable; 3 - Characterized and well-understood process; 4 - Process measured and controlled, and 5 - Focus on continuous improvement. It is important to emphasize that the questions presented in this table were based on those suggested by Quintela and Rocha (2007); however, they have undergone minor changes, mainly related to the reduction of sentences and vocabulary simplification, after the pilot test carried out in the first case studied. Table 2 shows the questionnaire used to collect data in all other cases that will be presented later.

Table 2: Questions to determine the maturity level

\begin{tabular}{|c|c|}
\hline \multicolumn{2}{|r|}{$\begin{array}{l}\text { Topics addressed in the questions used to verify compliance with goals and practices in the evaluated } \\
\text { process - for each maturity level }\end{array}$} \\
\hline & $\begin{array}{l}\text { Questions } 1 \text { to 7: } \\
\text { - New product designs are planned, with the stakeholder's involvement; } \\
\text { - Corrective actions are established when the product design is not happening as planned; } \\
\text { - Requirements for the project are collected, updated and can be accessed by the customer to the final } \\
\text { product; } \\
\text { - Documentation required for product development (PD) is maintained, identified, controlled, and } \\
\text { audited; } \\
\text { - The PD details have their performance evaluated according to the initial planning; } \\
\text { - All the company's projects have their requirements, products, and services managed and the processes } \\
\text { - } \text { planned, executed, measured, and controlled; } \\
\text { The PDP activities, situation, and results are reviewed with Top Management. }\end{array}$ \\
\hline 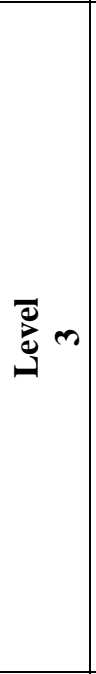 & $\begin{array}{l}\text { Questions } 8 \text { to 19: } \\
\text { - Information related to PDP planning and execution (metrics and expected results); } \\
\text { - The company's standard processes are established and maintained; } \\
\text { - The company's training needs are identified; } \\
\text { - There is a training program to ensure that the staff involved in the development has the required } \\
\text { knowledge and skills; } \\
\text { - Those involved in new product development (NPD) have a shared vision of the project; } \\
\text { - The integration and collaboration among those involved in the NPD are encouraged; } \\
\text { - The risks in the development and possible responses are identified, evaluated, and documented; } \\
\text { - The customer's needs are identified; } \\
\text { - The requirements are converted into product concepts; } \\
\text { - The developed product meets the delimited requirements, from the initial PDP to the final product } \\
\text { verification; } \\
\text { - The customer is involved in this verification process, validating it; } \\
\text { procedures, tools, and methods. }\end{array}$ \\
\hline & $\begin{array}{l}\text { Questions } 20 \text { to 24: } \\
\text { - The business objectives of the organization are deployed in quantitative objectives; } \\
\text { - Such quantitative goals are based on the customer's needs; } \\
\text { - The performance management techniques of the process and product - quantitative and statistical - } \\
\text { are applied; } \\
\text { - Significant variations in the process performance can be distinguished from random variations (noise); } \\
\text { - The risks involved in introducing a new product, technology or area of expertise or application are } \\
\text { known and managed. }\end{array}$ \\
\hline
\end{tabular}


DOI: 10.14807/ijmp.v11i7.1201

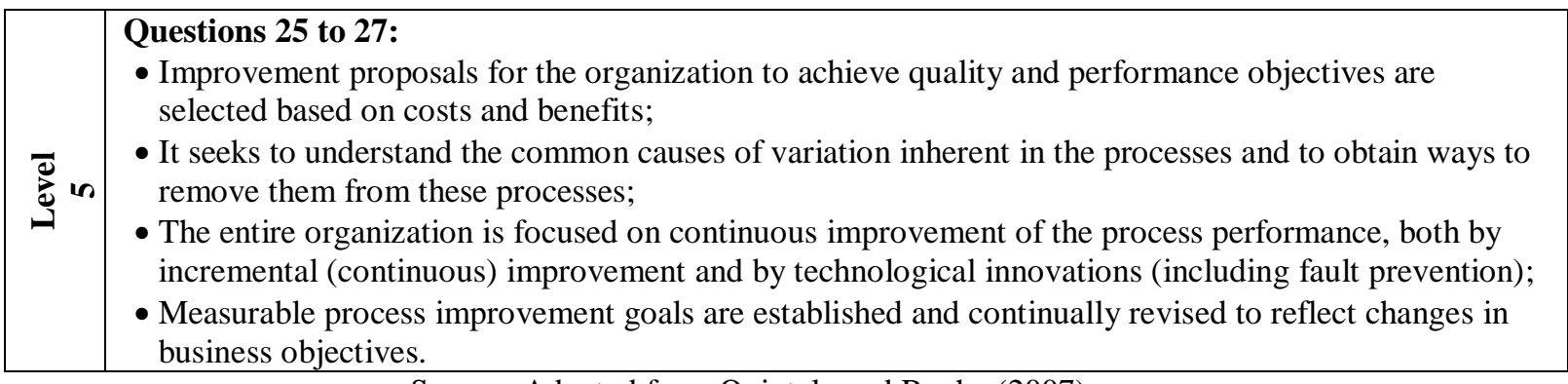
Source: Adapted from Quintela and Rocha (2007)

In order to evaluate the maturity level, it is necessary to observe the accomplishment level of the activities and their completed level, including the development quality. However, when talking about Quality Certification, it is important to establish how to put into practice structured methodologies to develop the projects, how much control one must have over the projects and manufacturing processes, and how much one can absorb the lessons learned from previous projects. It is important to notice that the main point is a problem of planning and standardization of processes, requiring consistency in their execution and management. In order to better understand this theme, a brief review will be presented.

\subsection{Quality and Certification}

Quality Certification is an indicator to consumers and companies that the product, process or service meets the pre-set minimum quality standards. In order to accomplish this, an international standard, known as the International Organization for Standardization (ISO) is described below (CARVALHO; PALADINI, 2013).

According to Cerqueira (2006), the ISO 9000 series consists of three main norms: NBR ISO 9000, NBR ISO 9001 and NBR ISO 9004. The ISO 9001 certification is recognized worldwide in a number of productive sectors. To obtain this certification, it is necessary to document the quality system and then to execute the work processes according to the documented procedures. Periodic audits (internal and external) are required to verify if the company continues to operate according to the previously documented procedures (MOTT, 2001; ROSS, 2017).

ISO 9001 is structured in 09 (nine) sections that can be divided into 02 (two) parts: General and Requirements. The first part, "General", describes the standard overall content, its application, definitions and others. The second part, "Requirements", defines the requirements necessary for the implementation and maintenance of a Quality Management System. These requirements are within five specific sections, according to the numbering presented: 4. Quality 
DOI: 10.14807/ijmp.v11i7.1201

Management System; 5. Management responsibility; 6. Resource Management; 7. Product realization; 8. Measurement, Analysis, and Improvement. As can be seen, only Section 7 addresses the activities related to the "product development process" and, therefore, will be the only item to be detailed (TONINI et al., 2008).

Section 7 is divided into six requirements: 7.1 Product Planning and Realization; 7.2 Processes Related to Customers; 7.3 Design and Development; 7.4 Acquisition; 7.5 Production and provision of services; and 7.6 Control of monitoring and measuring equipment. Among them, the requirement 7.3 details the items necessary in "Design and Development", emphasizing that the organization must plan and control product design and development, manage interfaces between different groups involved in design and development, ensure effective communication and clearly assign responsibilities. In addition, the company must also determine the internships, critical analysis, verification and validation appropriate to each stage, as well as determine the responsibilities and authority in design and development (TONINI et al.,2008).

Finally, as can be seen, the standard has guidelines that indicate that the company must plan, control and manage some activities, as well as ensure communication and assign responsibilities, but does not address operational details, which involve "how the company should develop and operationalize information during the project”, as CMMI and its derivative approaches address.

Therefore, according to Mott (2001) and Ross (2017), the conformity of the standardization of good process practices will not be different from the standardization of the practices of a bad process. As it turned out, for a company to guarantee its customers that its products are reliable, it certifies itself. However, "Certification" is not always synonymous for quality products. After all, good product means good process or mature processes.

\section{RESEARCH METHODOLOGY}

In order to reach the general objective, this study carried out a bibliographical review about the main topics involved in this research, as cited in item 2. Moreover, this work did a state-of-the-art review, based on the key words “capability maturity model”, “CMM”, "ISO 900", "relation", and "industry", aiming to identify similar or tangential works on the main academic database like Elsevier, Emerald, and other 256 fonts, shown in item 1.

Aiming to understand the PDP maturity level of food industry and its compatibility with the Quality Certification status, the study conducted a survey. Considering the existence of 
DOI: 10.14807/ijmp.v11i7.1201

several companies in this sector and the possibility of their participation, this paper conducted a multiple cases study in five companies, according to Yin (2011) guidelines.

According to Yin (2011), this method falls within as a qualitative approach and is used to collect data in the field of organizational studies. According to Donaire (1997), this methodology can also be applied when it requires a broadening of the knowledge on certain issue which, in the case of the present survey, aims to identify the correlation between the PDP maturity level and the ISO 9001 certification process. In order to apply the case study, Yin (2011) suggests to develop it in six phases, executed as follows:

Choice of case: Among 117 food and beverage industries of Parana (FIEP, 2012), 15 were located in Curitiba (city where the authors live), but only 5 industries accepted to participate in this survey project;

1. Design the Protocol of data Collection: the method used to collect the data was the CMMI simplified version, proposed by Quintella and Rocha (2007), added by the following questions about Quality Certification: Q1) Does the company have the Quality Certification? If so, Q2) when was it certified and which company certified it?; Q3) Does the company pretend to obtain the Quality Certification in the near future? If so, in how long?; Q4) Doe the company export products? If so, how many products does it export and to which countries? Aiming to test the questionnaire of Quintella and Rocha (2007) in this industrial sector, the pilot test was performed in Company A. From the outcome, it was possible to develop a new version, resulting in more familiar and clear expressions, according to what was shown previously in the Table 2;

2. Conduction of the case study: initially, there was an explanation about the company's PDP of all cases studied, since the design until fabrication, including the entrance and control of raw materials procedures involved. After this phase, the data collection starts through interviews with managers, production supervisors or persons that have knowledge of the production system, after a brief explanation of this survey. Such questions aimed to assess the achievement of goals considering the evolutive scale ( 1 to 5 ) and checked the existence of some certification or the intention of achieve it, including the status of products exportation. The five companies surveyed, including that submitted to pilot test, were named as companies A, B, C, D, and E. The companies A, B and C are large sized, the company $\mathrm{D}$ is small, and the company $\mathrm{E}$ is medium sized, according to SEBRAE classification (2013): Small - 20 to 99 employees; Medium - 100 to 499 employees; and 
DOI: 10.14807/ijmp.v11i7.1201

Large - more than 500 employees. The number of respondents in each company was: company A (1); company B (2); company C (1); company D (2) and company E (1). The number of respondents chosen varied according to the availability offered by the company and the respondent vision;

3. Development of written report: After the interview in each company, the median of each group of questions was calculated, concerning key-questions, according to the methodology presented by Quintella and Rocha (2007). According to the authors, the study considered the following rule: the organization reaches certain level if the level of all answers of this group is bigger or equal to 4 (that means “frequently” or “always”). In this work, the scale used was from 1 to 5, that indicates: 1 (never), 2 (rarely), 3 (sometimes), 4 (frequently), and 5 (always). If any answer of a group is lower than 4 , it means that the goals were not satisfactory in the company for the level of the questions analyzed, even though the median of this group could be 4 or 5 . For example, if a group of questions ( 1 to 7 - level 2) has one answer below 4, though the median of this group reaches value 4, the PDP will not consider level 2, but a level previously below, that is, level 1;

4. Standardization and Theoretical Modification: After the case study, this work conducted the analysis of information obtained in each company. Afterwards, this information was compared aiming to understand the sector status. However, it is worth pointing out that, because of the low number of respondents, these data cannot be generalized for the sector; it is valid only as a status indicative in the Metropolitan Region of Curitiba.

\section{CASE STUDIES}

The results of each company are presented in the following sequence: a brief history of the company, respondents' identification, the completion of Table 3 with questions referred to the maturity levels and respective answers and medians, including Table 4, which presents answers related to Quality Certification. Questions about Quality Certification are mentioned as Q1, Q2, Q3 e Q4, previously cited in the item 3.

\subsection{Case Study: Company A (Pilot Test)}

The company A, where the pilot test was performed, starts by the comprehension of the entire PDP, aiming to obtain the company's general overview and its resulting products. Founded in 1977, it is a large company located in Curitiba, south of Brazil, and it processes pork meat and milk. The company is present in more than 20 countries and, in Brazil, is ranked in an outstanding position among the major food industries of the country. In this survey, the 
ISSN: 2236-269X

DOI: 10.14807/ijmp.v11i7.1201

data collection was carried out with the manager of the Quality System Management. The results obtained through the questionnaire are presented in Tables 3 and 4.

Table 3: Results from the questionnaire of company A

\begin{tabular}{|l|c|}
\hline GROUPS OF ISSUES THAT DEFINE THE MATURITY LEVELS AND ITS ANSWERS & Medium \\
\hline $\begin{array}{l}\text { It seeks to identify if the PDP is in Level } 2 \text { of the CMMI } \\
\text { Answer: No, despite having obtained a median } 4 \text { in the group, the respondent indicated that the } \\
\text { projects and processes are not measured and controlled, and the results do not have a Management } \\
\text { review process. }\end{array}$ & $\mathbf{4}$ \\
\hline $\begin{array}{l}\text { It seeks to identify if the PDP is in Level } 3 \text { of the CMMI } \\
\text { Answer: No, they demonstrate a low maturity level. These items are related to the planning and } \\
\text { execution of processes for improvement; this data is collected, but not documented. Integration and } \\
\text { collaboration among those involved in new product development do not officially have an } \\
\text { integration-oriented metrics. Another issue that demonstrated low level is related to customers, who } \\
\text { are not involved in the verification process; they only give their feedback after the occurrence. }\end{array}$ & $\mathbf{3 , 5}$ \\
\hline $\begin{array}{l}\text { It seeks to identify if the PDP is in Level } 4 \text { of the CMMI } \\
\text { Answer: No. Although the median is equal to 4, the process and product performance management } \\
\text { techniques (quantitative and statistical) are not applied. According to the respondent, the board only } \\
\text { conducts a qualitative analysis. The process variations are not previously identified or documented. } \\
\text { They solve problems only at the moment they occur, without preventing future recurrences.. }\end{array}$ & $\mathbf{4}$ \\
\hline $\begin{array}{l}\text { It seeks to identify if the PDP is in Level } 5 \text { of the CMMI } \\
\text { Answer: No. The respondent stated that proposals (innovative and incremental improvements) for } \\
\text { the organization to achieve process quality and performance objectives are selected on the basis of } \\
\text { benefits and costs, not including documentation or controls. }\end{array}$ & $\mathbf{2}$ \\
\hline
\end{tabular}

Source: Authors

Table 4: Results on questions related to the Company A

\begin{tabular}{|l|l|}
\hline \multicolumn{2}{|c|}{ QUESTIONS RELATED TO CERTIFICATION } \\
\hline QUESTIONS & ANSWERS \\
\hline Q1: Does it have Quality certification? & $\begin{array}{l}\text { Among 5 unities in Parana, 2 are certified. The company } \\
\text { interviewed does not have certification. }\end{array}$ \\
\hline $\begin{array}{l}\text { Q2: When was it certified and by which } \\
\text { company? }\end{array}$ & Not certified \\
\hline $\begin{array}{l}\text { Q3: Does it intend to achieve a Certification? If } \\
\text { so, until when? }\end{array}$ & $\begin{array}{l}\text { The company seeks to be certified in short time and is } \\
\text { already being prepared for it. }\end{array}$ \\
\hline $\begin{array}{l}\text { Q4: Does the enterprise export products? If so, } \\
\text { how many products does it export and to which } \\
\text { countries? }\end{array}$ & $\begin{array}{l}\text { This unity does not export products due to limitations of } \\
\text { transport, warehousing and the variety of products. }\end{array}$ \\
\hline
\end{tabular}

Source: Authors

According to the results obtained, the company A is in level 1 of maturity, has no Quality Certification and does not export products, but demonstrates the intention to be certified in short time. Despite the company A presented level 1 of maturity, it presents strengths such as the planning of product integrated development and develops the documents requirements, such as information about designs and specifications. However, the company 
DOI: 10.14807/ijmp.v11i7.1201

presents some weaknesses that should be improved to reach the sufficient and necessary maturity level to obtain the quality certification.

Among the main lacks, it is possible to list the following ones: the company does not present metrics, measurements or assessment for the performance of planning and execution of the new products development process. Also, it presents a lack of shared vision of persons involved in the project in order to follow the inter-dependencies existing in this process.

Considering that this company was the first one to be studied, the questionnaire was adjusted, aiming a better comprehension of the other companies.

\subsection{Case Study: Company B}

The company was founded in 1968, keeping the commitment to invest in technology research and development in the food sector. The company produces dehydrated vegetables and fruits, cereal bars, and other products of this nature. In 2001, the company implanted the Balanced Score Card (BSC), whose method aims to establish the company strategies, considering four perspectives: finances, clients, internal processes, and learning. It has a branch in Arceburgo, in southern Minas Gerais/Brazil. It operates with 650 collaborators in Curitiba.

In order to survey the maturity level of Company "B", the data collection was carried out by interviewing the Manager of New Products Development Process and with the Manager of the Quality Management System, using the same protocol showed in the previous case.

Company B is at maturity level 1 and does not have quality certification. The company does not seek certification at present and exports some products to Japan and Africa. The company has the PDP well delimited, controlled, and focus on continuous improvement. Despite these positive characteristics, the company is maturity level 1 because its inefficiency in the informational design phase; it doesn't have a methodology to identify the client's requirements, to convert into product technical specifications. Including, the company itself reported the consequence of this inefficiency, presenting a product which was rejected by consumers and forced to withdraw from the market in the past.

\subsection{Case Study: Company C}

Located in Araucaria city - Paraná, Company C operates with 450 collaborators; therefore, it is a large company. The company operates in several sectors of byproducts of soybean, since the reception, warehousing, and grinding of soybean, to lecithin production, production and fill out of refined oil, production of protein concentrated bran (SPC), and 
DOI: 10.14807/ijmp.v11i7.1201

alcohol. In order to survey of the maturity level, the data collection was carried out by interviewing the Manager of Quality System Management, using the same protocol showed in the previous case.

Company $\mathrm{C}$ is at maturity level 2. It possesses the quality certification since 10 years ago and exports $90 \%$ of its products to Europe. After all, it can be said that despite the company presented the maturity level 2, it possesses strengths such as characterized processes, comprised, maintained, and controlled. In addition, the company presents some weaknesses such as lack of integration of the team related to PDP and lack of stimulus in the integration and collaboration among persons involved in the new products development.

\subsection{Case Study: Company D}

The company manufactures products derived from cocoa-bean and chocolate. It operates in the whole national territory and sells through 23 distributors. The manufacturing plant is located in Piraquara, Paraná, with 55 collaborators, and is a small Company. The data collection was performed by interviewing the Processes manager and the Company Director, using the same protocol showed in the previous case.

Company D is at maturity level 1 and does not have the Quality Certification. The company searches for certification, but it doesn't have a deadline to accomplish that. It can be said that despite Company D presents level 1, it possesses strengths such as the operation with direct contact with clients, identifying their real needs. However, the company presents some weaknesses: lack of integration among the persons involved in PDP; lack of training for the required abilities for design; lack of support methodologies in some design activities and lack of identification in the roles of each person involved in PDP.

\subsection{Case Study: Company E}

The company started the production in Brazil in 1971 and is located in Curitiba. The company has more seven branches in the south of Brazil. The company operates with 155 direct collaborators; therefore, it is a small Company, with cereal processing and trade activities. For this survey, the data collection was carried out by interviewing the Food Engineer, in charge of all processes in the Curitiba's branch, using the same protocol showed in the previous case.

Company $\mathrm{E}$ is at maturity level 1 and does not have the Quality Certification, but there is a preview of obtaining it in the next five years. The company does not export products. Although the company presents level 1 , it has strengths such as new products planning, with measurements and performance assessment, and the possibility to take corrective actions when 
ISSN: 2236-269X

DOI: 10.14807/ijmp.v11i7.1201

required, supported by the Top Manager. However, the company presents some weaknesses: lack of integration of the persons involved in PDP and lack of a methodology for the design phase, particularly, for developing the informational design, aiming to identify the clients' requirements and to convert them into design technical requirements.

\subsection{Analysis of the Results}

Among the five companies surveyed, all of them have low maturity levels, with poorly controllable processes and, in some points, unpredictable. Company $\mathrm{C}$ had the biggest maturity level, if compared to the other companies, being able to repeat some PDP tasks, but it is still considered immature, as can be seen in Table 5. This company is the only one that has the Quality Certification. Other companies (A, D, and E) still plan to apply to get the certification and Company B has no prediction to accomplish it. Regarding the products exportation, Companies B, C, and D export their products and Companies A and E do not export them yet.

Table 5: Demonstration of results of companies analyzed

\begin{tabular}{|c|c|c|c|c|}
\hline $\begin{array}{c}\text { Companies of } \\
\text { the food } \\
\text { Sector }\end{array}$ & $\begin{array}{c}\text { Level of } \\
\text { Maturity }\end{array}$ & Actual Certification & $\begin{array}{c}\text { Perspective of } \\
\text { Certification }\end{array}$ & $\begin{array}{c}\text { Export of Products / } \\
\text { Countries }\end{array}$ \\
\hline A & 1 & NO & YES & NO \\
\hline B & 1 & NO & NO & YES / Africa and Japan \\
\hline C & 2 & $\begin{array}{c}\text { YES (ISO 9001:2000/ } \\
\text { APPCC / GMPB 2) } \\
\text { since 2003 }\end{array}$ & Has certification & YES / Europe \\
\hline D & 1 & NO & YES & YES / Paraguay \\
\hline E & 1 & NO & YES & NO \\
\hline
\end{tabular}

$$
\text { Source: Authors }
$$

An analysis-synthesis of all cases can highlight some aspects that the companies require to improve their maturity levels. On the other hand, the companies have some aspects related to the high maturity performance, although they do not present high maturity level (See Table $6)$.

Table 6: Comparison of the results found in the Companies surveyed

\begin{tabular}{|c|c|c|}
\hline Company & Main failures in PDP & Main Strong points in PDP \\
\hline $\begin{array}{c}\text { Company } \\
\text { A } \\
\text { Level } 1\end{array}$ & $\begin{array}{l}\text { - The company does not present metrics, } \\
\text { measurements or assessment of planning and } \\
\text { execution performance of the new products } \\
\text { development process; } \\
\text { - There is a lack of shared vision of the } \\
\text { involved persons in the projects for } \\
\text { monitoring the interdependences existing in } \\
\text { the process. }\end{array}$ & $\begin{array}{l}\text { - Planning for product integrated } \\
\text { development; } \\
\text { - Development of the required documents, } \\
\text { such as information of projects and } \\
\text { specifications; } \\
\text { - Corrective actions when occurring process } \\
\text { variations; } \\
\text { - Methodology applications to convert the } \\
\text { clients' requirements into concepts of } \\
\text { products. }\end{array}$ \\
\hline
\end{tabular}


ISSN: 2236-269X

DOI: 10.14807/ijmp.v11i7.1201

\begin{tabular}{|c|c|c|}
\hline $\begin{array}{l}\text { Company } \\
\text { B } \\
\text { Level } 1\end{array}$ & $\begin{array}{l}\text { - There is a gap in the informational design } \\
\text { phase, related to the identification of the } \\
\text { clients' requirements; } \\
\text { - There is a lack of methodologies to convert } \\
\text { the clients' requirements into product } \\
\text { specifications. }\end{array}$ & $\begin{array}{l}\text { - A well delimited PDP, controlled and with } \\
\text { focus on the continuous improvement; } \\
\text { - Use of the Stage-Gate structure (Systematic } \\
\text { process for the assessment at the end of } \\
\text { each phase of PDP); } \\
\text { - Use of their own design methodology, } \\
\text { although fails in some specific points. }\end{array}$ \\
\hline $\begin{array}{l}\text { Company } \\
\text { C } \\
\text { Level } 2 \\
\end{array}$ & $\begin{array}{l}\text { - There is a lack of team integration related to } \\
\text { the PDP; } \\
\text { - Problems with integration activities. }\end{array}$ & $\begin{array}{l}\text { - Characterized processes, comprised, } \\
\text { maintained, and controlled. }\end{array}$ \\
\hline $\begin{array}{l}\text { Company } \\
\text { D } \\
\text { Level } 1\end{array}$ & $\begin{array}{l}\text { - There is a lack of integration among the PDP } \\
\text { members; } \\
\text { - There is a training lack for the required } \\
\text { abilities for the project; } \\
\text { - There is an identification lack of roles for the } \\
\text { PDP members. }\end{array}$ & $\begin{array}{l}\text { - Work close to clients, identifying its real } \\
\text { necessities. }\end{array}$ \\
\hline $\begin{array}{l}\text { Company } \\
\text { E } \\
\text { Level } 1\end{array}$ & $\begin{array}{l}\text { - There is a lack of integration among the PDP } \\
\text { members; } \\
\text { - There is a lack of methodologies to convert } \\
\text { the clients' requirements into product } \\
\text { specifications. }\end{array}$ & $\begin{array}{l}\text { - Planning for new products, with } \\
\text { measurement and performance assessment; } \\
\text { - Corrective actions when required and the } \\
\text { Top Management participation. }\end{array}$ \\
\hline
\end{tabular}

Source: Authors

From the results obtained, the study observed that Company A did not attain the maturity level 2 due to the metrics lack, performance assessment on planning and execution of the new products development, Also, it is not promoting shared vision among the involved. The company does not possess the quality certification and doesn't have a perspective to obtain in short time. For that, it would require of their weaknesses improvement, besides to maintain the planning activities of product integrated development with documentation to attain the maturity level 2, necessary to get the quality certification.

Company B did not reach maturity level 2 and does not possess certification, but expects to accomplish it in short time. Yet, the company exports products to Africa and Japan. This exportation is directed to countries which do not demand ISO 9001 certification, different from Europe countries, EUA, and others. The weakness of Company B is related to the lack of identification and survey on the clients' requirements in the informational design phase to convert them into technical requirements. Despite this, it possesses a well delimited PDP and controls its design development

Company D reached maturity level 1. Its weakness is related to the integration of the persons involved in PDP. Despite not possessing the certification, the company exports its products to Paraguay and intend to get the certification in short time. In this case, Paraguay is a country that does not demand ISO 9001 certification. Although the company operates in direct contact with clients, identifying their real needs, it has difficulties to identify the roles of 
DOI: 10.14807/ijmp.v11i7.1201

each person involved in PDP and does not promote training for required design abilities, aspects that hinder the improvement of industrial maturity and the issue of the certification.

Company E reached maturity level 1, as it does not possess certification nor export products. The company performs measurements and assessment of performance in the new products planning but faces difficulties to collect the clients' requirements and does not apply a methodology for that. Besides, the processes standardization is precarious, which is a poorly controllable and unpredictable condition. Thus, the company faces difficulties to repeat tasks, which hinders the issue of the Quality certification. Despite such difficulties, the company takes corrective actions when necessary, with the Top Manager participation.

The common failures among companies with maturity "level 1" were: lack of measurement and control during the products and services development, lack of identification and control of the documents required to PDP, integration problems among project teams, poor standardization of processes, and lack of methodologies to convert the clients' requirements in technical specifications.

Ending this survey work, the study noticed that there is a correlation between "PDP maturity" and "Quality Certification". Companies that have been certified longer have more mature processes, considering that the maturity level 2 is the minimum required for the company to present some of the requirements demanded by ISO 9001 Certification.

\section{CONCLUSIONS}

This survey analyzed the maturity level of the company's PDP in food industry, aiming to identify some relationship with the Quality Certification. Five companies were surveyed, showing coherence in their results. The study applied a method composed of 27 questions, divided into four groups of key issues. Each group of questions represents the goals that the company must meet to be at a certain maturity level, considering the evolutive scale (minimum 1 to maximum 5). Also, the study checked the existence of certification or the intention to obtain it, including the status of products exportation.

Among the five companies surveyed, four companies presented maturity level 1 and did not achieve certification. They still plan to apply to get the certification and one of them still have no prediction to obtain it. Only one company obtained maturity level 2 and had already achieved the certification in 2003 and remained stable. This shows a minimum maturity level demand to get the ISO certification and this "minimum" means "maturity level 2", considering the CMMI method. Level 2 means a managed process, which assures the technical 
DOI: 10.14807/ijmp.v11i7.1201

requirements, products and services managed appropriately, and processes planned, executed, measured, and controlled.

As shown, all companies presented a low maturity level, with poorly controllable processes and, in some points, unpredictable, including the company at level 2; after all, the maximum maturity level is 5 . The main failures are shown in Table 6 . Despite the low maturity level, the companies have some aspects related to high maturity performance as shown in the same table.

The common failures among companies with maturity "level 1" were: lack of measurement and control during the product and service development, lack of identification and control of required documents to PDP, integration problems among the project teams, few standardized processes, and lack of methodologies to convert the clients' requirements into technical specifications.

In general, the diagnosis pointed out several improvements demand: support methodologies for the product design phase, team competence to work better when inserted in the multidisciplinary groups and improve the process control with key performance indicators. Besides these improvements, the paper encourages the search for more design experts, especially in the informational design phase, including methods to identify the clients' demand, aiming to convert into design technical requirements, differentiating the mandatory from the desired requirements.

This phase is critical for the product development success, considering that the product requires the client's satisfaction and such success relies on how this phase is developed. In addition, the food industry shows some lack of documents and activities standardization, making the control and the achievement of the Quality Certification difficult.

For future research, the authors suggest to conduct the same study in other industrial sectors, aiming to verify if this relationship between "maturity and certification" occurs in the same way as in food industry.

\section{REFERENCES}

BACK, N.; OGLIARI, A.; DIAS, A.; SILVA, J. C. (2008) Draft Integrated Products. Planning, Design and Modeling. Barueri: Manole.

BAMFORD, R. C.; DEIBLER, J. W. (1993) Comparing, contrasting IS0 9001 and the SEI capability maturity model. USA: Ed.IEE

Brazilian National Standards Organization (2015) NBR ISO 9001:2000 Quality Management System - Requirements Rio de Janeiro, RJ. Brazilian Association of Food 
DOI: 10.14807/ijmp.v11i7.1201

Industries, ABIA, Annual Report of the Brazilian Association of Food Industries 2015. São Paulo, SP. [Online], Available at: https://www.abia.org.br/vsn/ (accessed 26 April 2015)

CARVALHO, M. M.; PALADINI, E. P. (2005) Quality management: theory and cases. Rio de Janeiro : Elsevier.

CERQUEIRA, J. P. E. (2006) Integrated management systems: ISO 9001, ISO 14001, OHSAS 18001, SA 8000, NBR 16001: concepts and applications. Rio de Janeiro : Qualitymark.

DAVID, M.; IDELMERFAA, Z.; RICHARD, J. (2005) Managing and Organizing Concurrent Processes According to the CMM Levels. Concurrent Engineering: Research and Applications, v. 13, n. 3, p. 241 -251.

DELLANA, S.; F. KROS, J. (2014) An exploration of quality management practices, perceptions and program maturity in the supply chain, International Journal of Operations \& Production Management, v. 34, n. 6, p. 786-806.

DONAIRE, D. (1997) The use of case study as a research method in the administration area. IMES journal, year XIV, n. 40, p. 9 -19.

ERIKSSON, H.; GREMYR, I.; BERGQUIST, B.; GARVARE, R.; FUNDIN, A.; WIKLUND, H.; SÖRQVIST, L. (2016) Exploring quality challenges and the validity of excellence models, International Journal of Operations \& Production Management, v. 36, n. 10, p. 1201-1221.

ESCRIG, A. B.; DE MENEZES, L. M. (2016) What is the effect of size on the use of the EFQM excellence model?, International Journal of Operations \& Production Management, v. 36, n. 12, p. 1800-1820.

ESTORILIO, C. C. A.; CAN, R. K. (2010) The reduction of irregularities in the use of process FMEA. International Journal of Quality and Reliability Management., v. 27, p. $721-733$.

ESTORILIO, C. C. A.; VAZ, G. R. M.; LISBOA, F. C.; BESSA, L. O. F. (2015) The relationship between industrial process maturity and quality certification. International Journal of Computer Standards \& Interfaces, v. 39, p. 22-33.

ESTORILIO, C. C. A.; SIMIAO, M.C.; SCHONOSKI, C.L.; LARA, M.C. (2008) Study of reducing manufacturing cost and assembly in a diesel engine with the aid of DFMA. Product \& Production (Print), v. 9, p. 5-14.

FIEP, Federation of Industries of the State of Parana. (2007) In: Database directory of the Registry of Industries of Paraná. Curitiba, CD- ROM.

FULLER, G. W. (1997) New Food Product Development : From Concept Marketplace, CRC Press LLC, Florida.

GARZÁS, J.; PINO, F. J.; PIATTINI, M.; FERNÁNDEZ, C. M. (2013) A maturity model for the Spanish software industry based on ISO standards, Computer Standards and Interfaces, v. 35, n. 6, p. 616-628.

GHOBADIAN, A.; GALLEAR, D. (1997) TQM and organization size, International Journal of Operations \& Production Management, v. 17, n. 2, p. 121-163.

HELGESSON, Y. Y. L.; HÖST, M.; WEYNS, K. (2012) A review of methods for evaluation of maturity models for process improvement, Journal of Software: Evolution and Process, v. 24, n. 4, p. 436-454. 
JOCHEM, R.; GEERS, D.; HEINZE, P. (2011) Maturity measurement of knowledgeintensive business processes, The TQM Journal, v. 23, n. 4, p. 377-387.

LISBOA, F. C. (2010) Maturity of Product Development and Quality Assurance Process: coherence found on Two Wheels Pole of Manaus. 2010. 134 f. Thesis (MSc in Engineering) - Graduate Program in Mechanical and Materials Engineering, Federal Technological University of Paraná, Manaus.

LOCKAMY, A.; MCCORMACK, K. (2004) The development of a supply chain management process maturity model using the concepts of business process orientation. Supply Chain Management: An International Journal, v. 9, n. 4, p. 272-278.

LOURENZANI, A. E. S. B.; TOLEDO, J. C.; LOURENZANI, W. L. (2002) Portfolio management - a case study in the food industry. Product Management Development, v. 1, n. 3.

MELLO, C. H. P. (2002) ISO 9001:2000: a quality management system for production and service operations. Sao Paulo: Atlas.

MOTT, J. D. (2001) ISO - 9000: Beyond Certification. London: Philip Crosby Associates.

OLIVEIRA, O.; J. FLORIAN, M. C. (2013) Implementation and ISO 9001 certification in a food service company. In: Symposium Engenhria Production, Proceedings, Bauru - SP.

OLIVEIRA, A. W. (2005) Maturity Models: Overview. Rio de Janeiro: Editora Mundo, 81p.

PAHL, G.; BEITZ, W. (2005) Design in Engineering: Fundamentals of Effective Product Development, Methods and Applications. 6. Ed. Sao Paulo: Edgard Blücher.

PĂUNESCU, C.; ACATRINEI, C. (2012) Managing maturity in process-based improvement organizations: a perspective of the Romanian companies, Journal of Business Economics and Management, v. 13, n. 2, p. 223-241.

QUINTELLA, H.L.M.; ROCHA, H.M. (2007) Maturity and comparison of PDPs automotive products. Production, Sao Paulo, v. 17, n. 1.

ROSS, J. E. (2017) Total quality management: Text, cases, and readings. Routledge.

ROZENFELD, H.; FORCELLINI, F. A.; AMARAL, D. C.; TOLEDO, J. C.; SILVA, S. L.; ALLIPRANDINI, D. H.; SCALICE, R. K. (2006) Management of product development: a reference for process improvement. Sao Paulo: Saraiva, 542 p.

SEBRAE / SC. (2013) Classification criteria for companies. Santa Catarina :.

SEBRAESC, 2013 Available at: <http://www.sebrae-

sc.com.br/leis/default.asp?vcdtexto=4154> Accessed on: May 8, 2013

SEI, Software Engineering Institute. (2010) CMMI for Development: Process Improvement Aiming Best Products (CMMI - DEV), Version 1.3. ed. Carnegie Mellon. Pittsburgh, PA, August 2010.

TEAM, S. U. (2011) Standard CMMI Appraisal Method for Process Improvement (SCAMPI) A, Version 1.3: Method Definition Document.

THELEN, M. J. (1997) Integrating process improvement, ISO 9000 and TQM in SITA Research and Development, The TQM Magazine, v. 9, n. 4, p. 265-269.

TONINI, A. C.; CARVALHO, M. M.; SPINOLA, M. M. (2008) Contribution of quality models and maturity in software process improvement. On- Line Production, v. 18, n. 2, p. 275-286. 
VAZ, G. R. M. (2010) Maturity of Product Development and Quality Assurance

Process: Coherence Found in Electrical and Electronic Industry of Manaus. 2010. 128 f. Thesis (MSc in Engineering) - Graduate Program in Mechanical and Materials Engineering, Federal Technological University of Paraná, Curitiba.

YIN, R. K. (2010) Case Study: Design and Methods. 4. Ed. Porto Alegre: Bookman. 